\title{
Use of Lemongrass Leaf Ethanol Extract for Developing Alginate Based Antibacterial Edible Films
}

\author{
Giyatmi Giyatmi, Hari Eko Irianto, Dina Fransiska, Nurhayati, Bintang Anggoro
}

\begin{abstract}
Alginates extracted from brown seaweed have a variety of prospective applications such as thickeners, stabilizers, or restructuring agents. Due to its properties as a natural polysaccharide, alginate is very potential to be used as edible films for food packaging purposes. Edible films are developed for food protection being excellent barriers to gases but not to moisture. Incorporation of antimicrobial agents into edible film formulation can extend product shelf life and reduce the risk of pathogenic bacterial growth on food. Therefore, this study was aimed to develop an alginate based antibacterial edible film. Antibacterial agent extracted from lemongrass leaves using ethanol was employed. The study was conducted by varying the addition levels of lemongrass ethanol extract to the alginate based edible films, i.e. $0.5 \%, 1.0 \%$ and $1.5 \%$. Before being added to the alginate based edible films, the lemongrass ethanol extract was investigated for its antibacterial activity. The edible films obtained were analyzed in terms of physical, mechanical and chemical and microbiological parameters, including thickness, water vapor transmission rate (WVTR), brightness, tensile strength, elongation, moisture content, water solubility and antibacterial activity. Results showed that the higher addition levels of lemongrass ethanol extract tended to produce alginate based edible films with lower WVTR and brightness value as well as higher elongation, moisture content and water solubility. Edible film added with lemongrass ethanol extract resulted in this study demonstrated antibacterial activity against Staphylococcus aureus. The addition of lemongrass alcohol extract at $0.5 \%$ was considered as a recommended concentration level for producing alginate based antibacterial edible films.
\end{abstract}

Keywords : Alginate, Edible Film, Antibacterial, Lemongrass, Ethanol Extract.

Revised Manuscript Received on December 15, 2020.

* Correspondence Author

Giyatmi Giyatmi, Study Program of Food Technology, Sahid University, Jakarta, Indonesia, Email: giyatmi@hotmail.com

Hari Eko Irianto*, Research and Development Center for Marine and Fisheries Product Processing and Biotechnology, Jakarta, Indonesia, Email: harieko_irianto@yahoo.com

Dina Fransiska, Research and Development Center for Marine and Fisheries Product Processing and Biotechnology, Jakarta, Indonesia, Email: dinanomo@gmail.com

Nurhayati, Research and Development Center for Marine and Fisheries Product Processing and Biotechnology, Jakarta, Indonesia

Bintang Anggoro, Study Program of Food Technology, Sahid University, Jakarta, Indonesia

(C) The Authors. Published by Blue Eyes Intelligence Engineering and Sciences Publication (BEIESP). This is an open access article under the CC BY-NC-ND license (http://creativecommons.org/licenses/by-nc-nd/4.0/)

\section{INTRODUCTION}

Seaweed is an abundant source of hydrocolloids in Indonesia, both from cultivation and harvested from nature. One of the hydrocolloids produced by extracting from seaweed is alginate. Alginate is a picocoloid compound produced from brown seaweed (Phaeophyceae). The brown seaweed from Indonesia's coastal waters that have the potential to be processed into alginate are Sargassum sp., Turbinaria sp., Hormophysa sp., and Padina sp. Those four alginophyte species are still harvested from nature [1]. The characterization results of alginate from Sargassum crassifolium, S. polycystum, Padina sp., S. echinocarpum, S. duplicatum, S. binderi, Turbinaria conoides and $\mathrm{T}$. decurrens growing wild on the rocky coast of Gunung Kidul, Yogyakarta showed 25-39\% viscosity, 46.2-52.3 brightness and $16.93-30.50 \%$ yield [2]. However, various alginates with a wide range of bioactive properties are available commercially, in which the properties are depending mainly on the length of the polysaccharide chain and the ratio of the mannuronic and guluronic sugars, thus allowing for a large potential use. In addition to good heat stability, their unique gelling abilities at low temperatures bring about them ideal for use as a thickener, stabilizer, or restructuring agent. Alginates also have uses in a wide variety of new food applications, from encapsulation of active enzymes and live bacteria, to acting as carriers for the protective coating of fruit and vegetables that are packaged, cut, or prepared [3]. Due to its property as a natural polysaccharide being viscous and soluble in water, alginate is very potential to be used as a bioplastic or edible film [4]. Edible films that are normally developed for food protection are excellent barriers to gases but not to moisture as polysaccharides and proteins must be included for their development. Many studies are looking for methods to reduce the water vapor permeability of thin films. Edible films are a much studied matrix because it can also be applied as a technological hurdle for food preservation. Meanwhile, its microstructure can be used to carry, stabilize, localize activity and control the release of food preservatives (antimicrobials, antioxidants) at the interface [5]. In addition to overcome the poor mechanical properties of alginate based edible films, glycerol is incorporated, as a plasticizer, to decrease the hydrogen bonding density between alginate chains. In active packaging,

Blue Eyes Intelligence Engineering and Sciences Publication

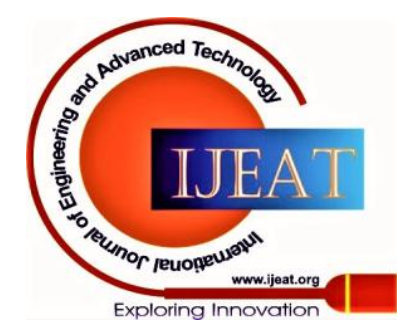


specific compounds as antioxidants, and antimicrobial materials are included in the edible films to extend their functionality and increase the food shelf-life [6]. Inclusion of antimicrobial agents into edible film formulation that can extend product shelf life and reduce the risk of pathogen growth on food surfaces have been conducted using preservatives and antimicrobials including benzoates, propionates, sorbates, parabens, acidifying agents (e.g., acetic and lactic acids), curing agents (e.g., sodium chloride and sodium nitrite), bacteriocins, and natural preservatives (e.g., essential oils, lysozyme, liquid smoke) [7].

Some natural antibacterials have been introduced to develop antimicrobial edible films, those are such as garlic water extract in gelatin edible film [8], beluntas leaf ethanol extract in cornstarch edible film [9], lemongrass oil in sago starch - alginate edible film [10], garlic oil in alginate edible leaf water extract in carrageenan - tapioca edible film [13].

The aims of this study were to explore the use of lemongrass leaves for developing alginate based antibacterial edible films. Antibacterial activities are demonstrated by lemongrass ethanol extract to Staphylococcus aureus [14], Streptococcus mutans [15], and Enterococcus faecalis [16]. In addition, lemongrass oil was found effective against Staphylococcus aureus, Bacillus cereus, Bacillus subtilis, Escherichia coli, and Klebsiella pneumonia [17]. Therefore, lemongrass leaves meet the requirements to be explored to use as an antibacterial source in the development of alginate-based edible films.

\section{MATERIAL AND METHODS}

\section{A.Materials}

Alginate powder was prepared by extracting from Sargassum sp. using an extraction method developed by Yunizal [18]. Fresh lemongrass was obtained from Leuwiliang Village, Bogor Regency, Indonesia. The modified cassava (mocaf) flour of "Ladang Lima" brand was used, while sorbitol and beeswax were purchased from PT Geochem Globalindo, Jakarta, Indonesia.

\section{B. Extraction of Alginate}

After harvesting, Sargassum was washed, soaked in $\mathrm{KOH}$ solution and sundried. Dried Sargassum was soaked in $\mathrm{NaOH}$ solution for 2 hours and neutralized by washing using fresh water. Alginate was extracted by boiling Sargassum in $\mathrm{Na}_{2} \mathrm{CO}_{3}$ solution for 2 hours, then filtered. The filtrate was blanched by adding $\mathrm{NaOCl}$ and then acidified with $\mathrm{HCl}$ to $\mathrm{pH}$ 2.5 - 3. The alginic acid formed was washed with water and added with $\mathrm{NaOH}$ to $\mathrm{pH} 9-10$. The sodium alginate formed was precipitated using isopropanol to obtain alginate fibers. After sundrying, the alginate fiber was ground to get alginate flour [18].

\section{C.Extraction of Antibacterial Compounds}

A modified method previously employed in an experiment was used to extract antibacterial compounds from lemongrass leaves [19]. First of all, the lemongrass leaves were washed, then cut into pieces before being mixed with ethanol. In order to obtain a perfect maceration process, lemongrass and film [11], ginger oil in uwi starch edible film [12] and teak

ethanol were mixed in a large and closed container. The soaking process was carried out for 3 days with stirring every 24 hours. The filtrate was filtered with a 100 mesh filter cloth and then transferred to a rotary vacuum evaporator to get thick extract.

\section{Preparation of Edible Film}

A modified method developed in a previous study was used to prepare edible film [20]. About $97 \mathrm{~mL}$ distilled water was heated in a beaker glass to $50^{\circ} \mathrm{C}$, then $1.5 \mathrm{~g}$ of alginate powder was added gradually while stirring with a magnetic stirrer. Subsequently, $0.3 \mathrm{~g}$ of mocaf starch was added with stirring for 30 minutes. After being completely mixed, the lemongrass ethanol extract was added to the solution at various levels $(0.5 \%$; $1 \%$; $1.5 \%)$ with stirring at $75^{\circ} \mathrm{C}$ for 30 minutes until well mixed. The edible film solution obtained was cast by pouring into a square acrylic plate. An edible film solution formula was cast on two acrylic plates. The acrylic plate was allowed to stand at room temperature for approximately 24 hours and then the dried edible film was peeled off.

\section{E. Experiment}

Before being added to the edible film, the lemongrass ethanol extract underwent antibacterial tests against Staphylococcus aureus and Escherichia coli at concentrations of $0.5 \%, 1.0 \%$ and $1.5 \%$. After that, the experiment was continued with the application of lemongrass ethanol extract as an antibacterial agent on alginate based edible film. The addition levels of the lemongrass ethanol extract tested were $0.5 \%, 1 \%, 1.5 \%$. The experiment was carried out with 2 replications.

\section{F. Analyses}

Performance of alginate based antibacterial edible films were assessed in terms of physical, mechanical, chemical and antibacterial properties including thickness, water vapor transmission rate, brightness, tensile strength, elongation, moisture content, and water solubility, as well as antibacterial activity for S. aureus and E. coli.

\section{1) Thickness}

The thickness of the film was measured using a Mitutoyo micrometer Serial No. 7301 (Mitutoyo Corp in Japan) with an accuracy level of $0.001 \mathrm{~mm}$ by placing the film between anvil and spindle of the micrometer. For each film sample, the thickness was measured at five different points. The film thickness value was determined by averaging the measurement values of all points and reported in mm [21].

\section{2) Water Vapor Transmission Rate (WVTR)}

WVTR is the amount of moisture lost per unit time divided by the cross-sectional area of the film. WVTR analyses were carried out using PERME $®$ W3 / 031 Water Vapor Transmission Rate Tester (Labthink, China). WVTR testing with this equipment refers to the dish method based on ASTM E96 [22] which is commonly used to measure WVTR of plastic films, composite films, sheets, 
and others. The principle of the test is to differentiate constant humidity (RH 90\%) between the two sides of the sample at a certain temperature $\left(38^{\circ} \mathrm{C}\right)$. Water vapor will penetrate through the sample and enter the dry side. The WVTR value is obtained by measuring the change in weight of the test dish within a certain time span (once every 60 minutes). The measurement results will automatically appear in the system after 24 hours with the following equation:

$$
\operatorname{WVTR}\left(\frac{g}{m^{2}} \cdot 24 \text { jam }\right)=\frac{\Delta m}{t x L}
$$

Note: $\Delta \mathrm{m}=$ change in water mass lost $(\mathrm{g})$

$\mathrm{T}=$ observation period (hour)

$\mathrm{L}=$ sample cross-sectional area $\left(\mathrm{m}^{2}\right)$

\section{3) Color $(\Delta E)$}

Measurement of the color of the film was carried out using a Colorimeter (ColorFlex EX, HunterLab, USA). The color was represented as a color difference $(\Delta \mathrm{E} *)$ [23]. White tiles $(\mathrm{L} *=94.20, \mathrm{a} *=1.09, \mathrm{~b} *=2.55)$ were used as film backgrounds and their color parameters were used to calculate the difference between the color parameters $(\Delta \mathrm{L}, \Delta \mathrm{a}$ and $\Delta \mathrm{b}$ ) of the samples and film backgrounds. The difference between the color parameters was used to determine $\Delta \mathrm{E}$ using a following formula:

$$
\Delta \mathrm{E}=\sqrt{\Delta L^{2}+\Delta a^{2}+\Delta b^{2}}
$$

\section{4) Tensile strength and Elongation}

Measurements of the tensile strength and elongation of the film were carried out using a texture analyzer (TAXT-Plus Stable Micro System, UK) [24]. The edible film sample was cut to a size of $15 \times 1.5 \mathrm{~cm}^{2}$ and clamped in the film grips with the initial grip distance of $10 \mathrm{~cm}$. The test speed was set at a speed of $2 \mathrm{~mm}$ / sec and stopped when the sample was cut off so that the peak load value could be determined. By dividing maximum force with the initial cross-sectional area of film, the tensile strength was calculated.

Percentage of change in the length of film strips from the initial length was defined as elongation.

$$
\begin{aligned}
& \text { Tensile Strength }(\mathrm{MPa})=\frac{\mathrm{F} \max }{\mathrm{A}} \\
& \text { Elongation }(\%)=\frac{\mathrm{L}_{1}-L_{0}}{\mathrm{~L}_{0}} \times 100 \%
\end{aligned}
$$

Note: Fmax $=$ Maximum force at break $(\mathrm{N})$

$$
\begin{aligned}
& A=\text { Cross-sectional area }\left(\mathrm{m}^{2}\right) \\
& \mathrm{L}_{0}=\text { Initial film length }(\mathrm{m}) \\
& \mathrm{L}_{1}=\text { Film length at break }(\mathrm{m})
\end{aligned}
$$

\section{5) Moisture Content}

About 5 grams of sample was put into a weighed dish and then dried in an oven at $105^{\circ} \mathrm{C}$ for 3 hours. The dish containing the sample was cooled in a desiccator and weighed until constant. Moisture content was calculated based on weight loss, which was the difference between initial weight and final weight of the sample (SNI-01-2354.2-2015) [25].

\section{6) Water Solubility}

The water solubility of edible film was determined referring to the modified method used in the previous study [26]. The film was cut to a size of $2 \times 2 \mathrm{~cm}^{2}$ and dried in an oven at $105^{\circ} \mathrm{C}$ for 24 hours and then weighed as initial weight

Published By:

Blue Eyes Intelligence Engineering and Sciences Publication

(C) Copyright: All rights reserved.
(Wo). The film samples were then transferred to a tube containing $30 \mathrm{ml}$ of distilled water for 24 hours at room temperature. After that, the insoluble film was filtered with Whatman No.1 filter paper, dried in an oven at $105^{\circ} \mathrm{C}$ for 24 hours, and weighed $\left(\mathrm{W}_{\mathrm{f}}\right)$ to determine the dry material that was insoluble in water.

$$
\begin{aligned}
& \text { Water solubility }(\%)=\frac{W_{o}-W_{f}}{W_{o}} \times 100 \% \\
& \text { Note: } W_{o}=\text { initial dry weight of film }
\end{aligned}
$$$$
\mathrm{W}_{\mathrm{f}}=\text { dried weight of insoluble film }
$$

\section{7) Antibacterial Activity}

Antibacterial activity was observed using the disc method with some modifications [27]. The samples were cut with a perforator (paper punch). About $2 \mathrm{~mL}$ of $E$. coli were added to a petri dish that was sterilized by autoclave, then added $5 \mathrm{~mL}$ of Nutrient Agar. Edible film samples were planted on the media after the agar hardened. Samples were kept in an incubator at $37^{\circ} \mathrm{C}$ for 24 hours, and then observed the formation of a clear zone reflecting inhibition level. The diameter of the clear zone around the film was measured using Scan ${ }^{\circledR} 1200$ Colony Counter (Interscience, France).

\section{RESULT AND DISCUSSION}

\section{A.Physical Properties of Edible Film}

Physical characteristics are very important to produce an attractive edible film suitable for use as food packaging. The physical properties observed in this study included thickness, WVTR and color of the edible film.

\section{1) Thickness}

The thickness of the edible film is usually influenced by the surface area of the casting plate and the total amount of solids in the film solution. The increase in the total amount of solids in the film solution brings about the polymers making up the matrix on the edible film to also increase. With the same size of casting plate, the more the volume of the edible film solution added, the ticker the film will be [28]. The thickness of alginate based edible film produced in this study was in the range of $0.101-0.107 \mathrm{~mm}$ (Fig. 1). The thickness of the edible film was much thinner compared to arrowroot starch-carrageenan based films, i.e. 0.240 - 0.644 mm [29] Concentration levels of lemongrass ethanol extract added insignificantly affected the thickness of alginate based edible films. Thus, the increasing amount of solids in the lemongrass extract added at the range of $0.5-1.5 \%$ did not affect the thickness of the film produced. The resulting film thickness meets the requirements of Japan International Standard (JIS), i.e. maximum $0.25 \mathrm{~mm}$ [30]. Different results were reported that the addition of active ingredients (grape seed extract and thymol) in the film increased the film thickness [31]. The thickness of the edible film was also revealed to be influenced by the type of antimicrobial materials used, in which betel extract produced a thicker edible film than turmeric and onion extracts [32]

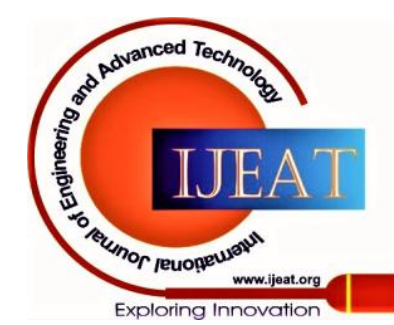




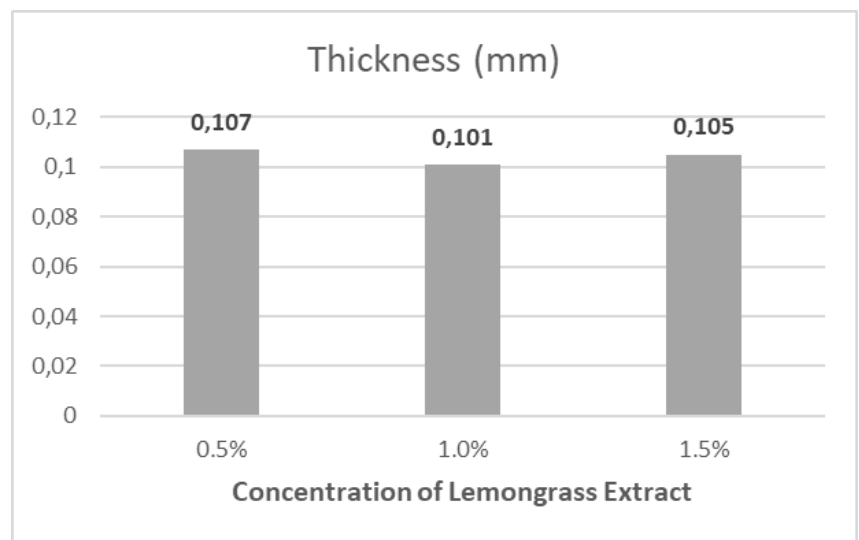

Fig. 1 Thickness values of alginate based antibacterial edible films

\section{2) Water Vapor Transmission Rate (WVTR)}

WVTR values are very important to know, because the values are used to estimate the shelf life of the packaged product. Food packaging with edible film is expected to be able to withstand moisture of the product from the environment and vice versa [33]. WVTR values of alginate based edible films incorporated with lemongrass extract at $0.5 \%, 1.0 \%$ and $1.5 \%$ were $2446,50,2252,99$ and 2069,33 $\mathrm{g} / \mathrm{m}^{2} .24 \mathrm{~h}$ respectively (Fig.2). Those results indicated a negative correlation between the addition of lemongrass ethanol extract and a decrease in WVTR, meaning that WVTR decreased as the concentration of essential oils increased. Thus, this study noted that the higher the addition levels of lemongrass ethanol extract resulted in alginate based edible film with a decreasing WVTR value.

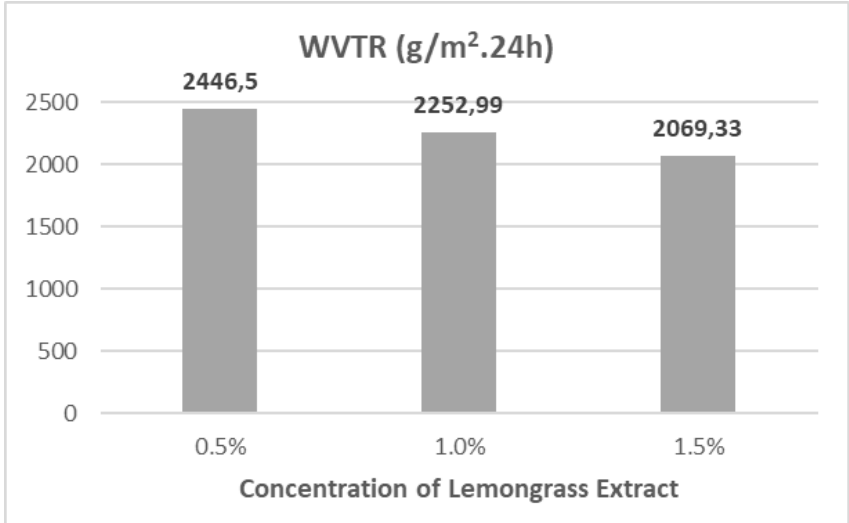

Fig. 2 Water vapor transmission rate (WVTR) values of alginate based antibacterial edible films

The main component of lemongrass leaf extract is essential oil. The water vapor transfer generally occurs through the hydrophilic part of the film and depends on the ratio of hydrophilic and hydrophobic components. The addition of essential oils which are hydrophobic lipids to the hydrophilic polymer film can improve WVTR performance of edible film [34]. Thus, WVTR decreasing with the addition of essential oils as shown in this study can be understood as a common phenomenon. Similar results were shown in the processing of cannabis starch edible film added with palm oil [30], carrageenan edible film added with palm oil [35] and carrageenan edible film added with garlic essential oil [34]. The reduction in WVTR is a direct contribution to the hydrophobicity of essential oil. Based on the results of the study, the WVTR value decreased when the lemongrass extract concentration increased. The presence of a hydrophobic group added to the edible film could inhibit the water vapor transfer [36]. Fatty acids in edible films made from composites are found to have an effect on reducing WVTR because fat has low polarity and a dense crystal structure [37].

3) Color $(\Delta E)$

Color of the edible film greatly affects its acceptance as packaging material, and also determines the application of the edible film for food packaging. There are products requiring packaging material with certain level of color, but there are also products that do not put color as a requirement for the packaging. The addition of lemongrass ethanol extract to alginate based edible film at a concentration of $0.5-1.5 \%$ produced films with a color values of 10.5-18.4 and the highest color value was shown by the addition of $1.0 \%$ lemongrass ethanol extract (Fig. 3). The difference in $\Delta \mathrm{E}$ values were reported to be influenced by the moisture content of the film. The higher moisture content affected the pattern of light reflection passing through the surface of the film thereby increasing the 'b' value (yellow-blue color) [38]. This study informed that the pattern of changes in the color value of the edible film due to the addition of lemongrass ethanol extract was similar.

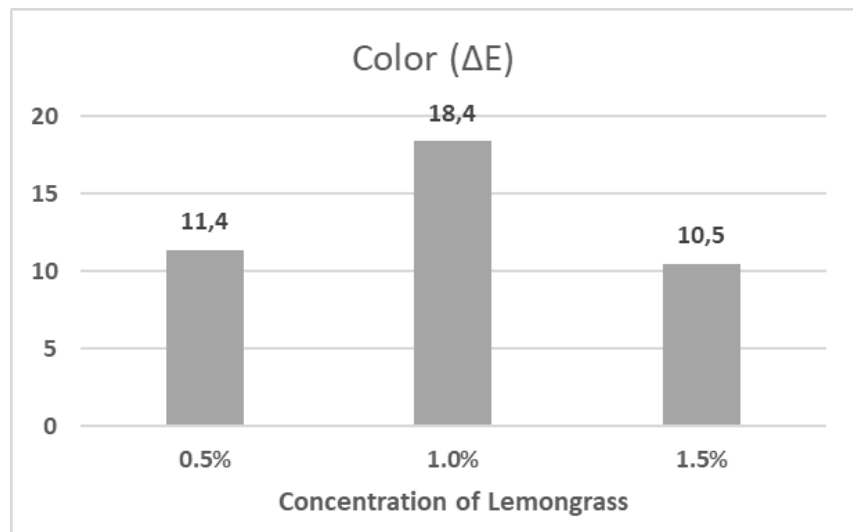

\section{Fig. 3 Color $(\Delta E)$ values of alginate based antibacterial} edible films

\section{B. Mechanical Properties of Edible Film}

The mechanical properties of edible films need to be revealed, because the mechanical properties can be used to estimate the ability level of edible films in overcoming mechanical influences in their applications. Important mechanical properties commonly used for edible films are tensile strength and elongation.

\section{1) Tensile Strength}

The tensile strength of the film is the maximum tension that can be achieved until the film remains on before the film is torn. Thus, tensile strength is a physical property related to the strength of the film to withstand physical damage as food packaging. The film with the highest tensile strength value is expected to be able to withstand maximum physical disturbances, so that the damage to the product will be minimized.

Published By: 
The tensile strength of the alginate based edible film added with lemongrass extract at a concentration level of 0.5 $1.5 \%$ was $1.31-2.48 \mathrm{Mpa}$ (Fig. 4). Statistically, the addition levels of lemongrass ethanol extract had no significant effect on the tensile strength values of the edible film produced. The tensile strength of alginate based edible in this study was better than the tensile strength of the Xanthosoma sagittifolium starch edible film incorporated with potassium sorbate, i.e. 0,399 -1,390 MPa [39].

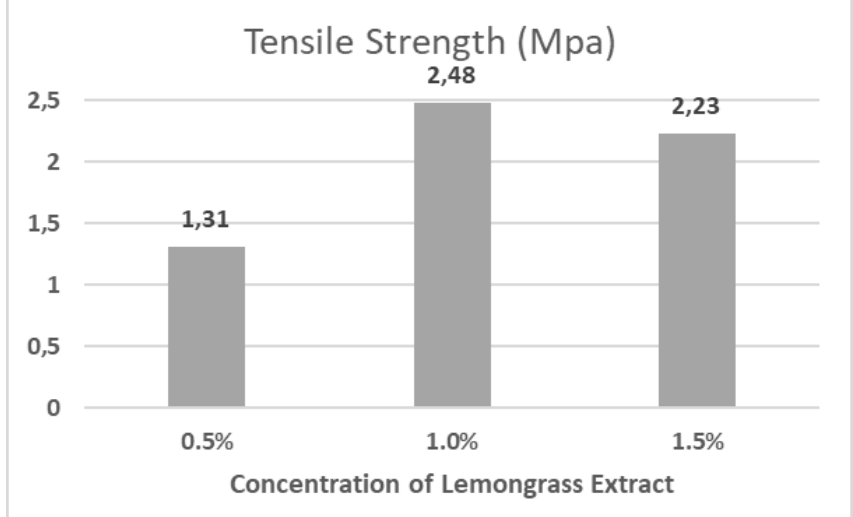

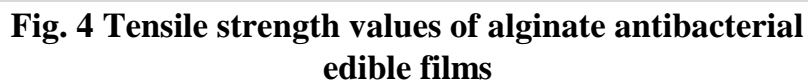

\section{2) Elongation}

Elongation is the percentage change in film length when the film is stretched. This change in length can be seen when the film breaks. The addition of lemongrass ethanol extract at concentration level of $0.5-1.5 \%$ resulted in edible film with an elongation value of $34.25-69.05 \%$. The highest elongation was demonstrated by alginate based edible film added with $1.0 \%$ lemongrass ethanol extract. According to the Japanese Industrial Standard - 1975, the elongation percentage of less than $10 \%$ is categorized as bad and if the elongation percentage of more than $50 \%$ is categorized as very good [40]. So, elongation value that meet the very good category was from alginate based edible film added with $1.0 \%$ lemongrass ethanol extract, i.e. 69,05\%. Meanwhile, elongation values of edible films made with the lemongrass ethanol extract addition of $0.5 \%$ and $1.5 \%$ were $34,25 \%$ and $48,65 \%$ respectively which were categorized as good. A higher percentage of elongation indicates that the film is more flexible.

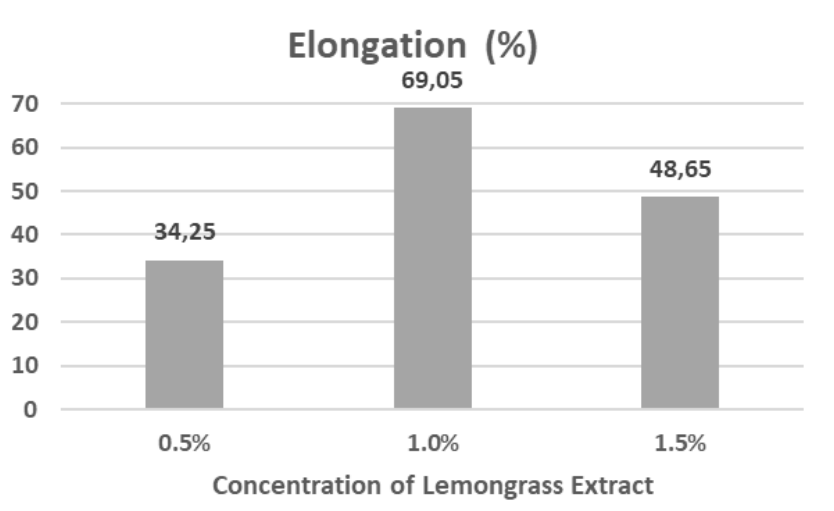

Fig. 5 Elongation values of alginate based antibacterial edible films

\section{C.Moisture Content and Water Solubility}

Those two parameters are very important for edible films. The moisture content of the edible film plays an important role in keeping the stability of the products in the packaging. Meanwhile, the solubility of edible film in water greatly determines the level of biodegradability.

\section{1) Moisture Content}

Alginate based edible films incorporated with lemongrass ethanol extract of $0.5 \%-1.5 \%$ had a moisture contents range of $11.11-13.12 \%$ (Fig. 6). Edible film with the addition levels of $1.0 \%$ and $1.5 \%$ lemongrass ethanol extract had a higher moisture content than the film with the addition of 0.5\% lemongrass ethanol extract. The increasing concentration of lemongrass ethanol extract in manufacturing edible film tended to increase the moisture content of the resulting edible film. Those results are in line with the trend occurred in edible films from whey protein with the addition of palm oil which is thought also to be applicable to alginate-based edible films, in which the more oil added, the higher the water content will be [41]. The presence of oil makes water trapped in the edible film, so that less water will evaporate when drying. This phenomenon was probably due to that lemongrass ethanol extract as an ingredient in edible films making may have increased the hygroscopicity of the films inducing higher moisture content. More sites were actually available to bind water in the film matrix because of the increased number of hydrophilic chains until a certain addition level of lemongrass ethanol extract. Moisture content has an influence on the characteristics of the edible film, especially on the physical properties of the edible film [42]. The higher the moisture content makes the edible film more brittle and softer texture.

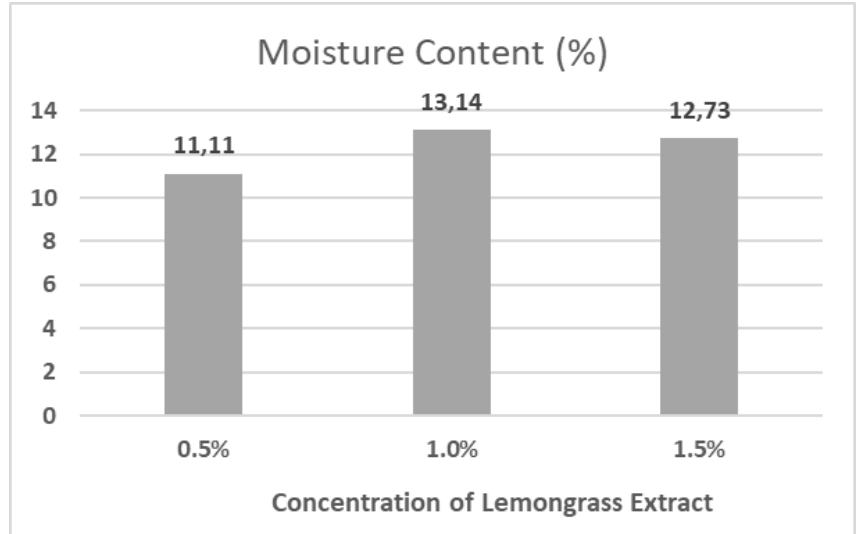

Fig. 6. Moisture contents of alginate based antibacterial edible values

\section{2) Water Solubility}

The solubility of edible film is an important factor that determines the biodegradability properties of the film as a food packaging. Water solubility of alginate based edible films incorporated with lemongrass ethanol extract at $0.5 \%$, $1.0 \%$ and $1.5 \%$ were $58.61 \%, 72.03 \%$ and $78.03 \%$ respectively. 
Meanwhile, the water solubility of $\kappa$-carrageenan-based edible film addede with various levels of alginate and PEG varied between $71.03 \pm 0.61 \%$ to $97.23 \pm 0.70 \%$ [43]

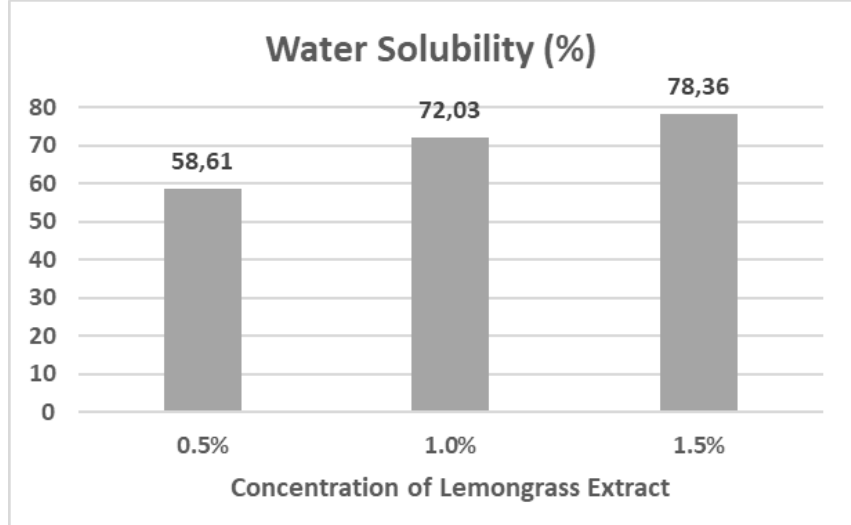

Fig. 7 Water solubility values of alginate based antibacterial edible films

The above results indicated that the higher concentration levels of lemongrass ethanol extract, the higher water solubility of the edible film. A similar trend in the manufacture of taro starch edible film added with galangal essential oil was reported that the more galangal essential oil was added to produce edible film with increased water solubility [44]. It was suspected that the addition of essential oils brought about the breakdown of polymer and hydrogen chain arrangements in starch, thereby increasing water solubility. Then there was a hydroxyl group in galangal essential oil, so that the greater the concentration of galangal essential oil resulted in the increased hydroxyl group in the taro starch based edible film [44]. Another study revealed that that the more hydroxyl groups in the edible film matrix induced increasing water solubility [30].

The high solubility makes the edible film to dissolve easily in water and this characteristic is required for use in ready-to-eat food products. Meanwhile, edible film with low solubility is suitable for use as packaging materials of high moisture content and water activity food products [45].

\section{D.Antibacterial Activity}

Before being added as antibacterial to the alginate based edible film, the ethanol extract of lemongrass leaves was tested for its antibacterial activity against Staphylococcus aureus and Escherichia coli using the disc method. The results indicated that the lemongrass ethanol extract showed antibacterial activity against $S$. aureus, but did not show antibacterial activity against E. coli (Table 1). Previous study also reported the antibacterial activity of lemongrass alcohol extract against $S$ aureus [14]. Although the lemongrass ethanol extract did not show antibacterial activity against $E$ coli, but another investigation proved that lemongrass oil demonstrated antibacterial effect on E. coli [17]. Clear zones reflecting antibacterial activity range of lemongrass ethanol extract against $S$. aureus at testing levels of $0.5 \%, 1.0 \%$ and $1.5 \%$ were $4.0 \mathrm{~mm}, 7.0 \mathrm{~mm}$ and $9.5 \mathrm{~mm}$ respectively (Table 12). It seems that the lemongrass ethanol extract tested at higher concentrations tended to produce higher antibacterial activity against $S$. aureus as indicated by the larger clear zone diameter.
Table 1. Antibacterial activity of the lemongrass ethanol extract against Staphylococcus aureus and Escherichia coli

\begin{tabular}{|c|c|c|}
\hline $\begin{array}{c}\text { Concentration of } \\
\text { Lemongrass Ethanol } \\
\text { Extract }\end{array}$ & \multicolumn{2}{|c|}{ Inhibition Zone (mm) } \\
\cline { 2 - 3 } & Staphylococcus aureus & $\begin{array}{c}\text { Escherichia } \\
\text { coli }\end{array}$ \\
\hline $0.50 \%$ & 4.00 & 0.00 \\
\hline $1.00 \%$ & 7.00 & 0.00 \\
\hline $1.50 \%$ & 950 & 0.00 \\
\hline
\end{tabular}

In regard to the above explanation concerning antibacterial activities of lemongrass extract and oil, the lemongrass ethanol extract actually has the potential to be used as an antibacterial agent against $S$ aureus and E. coli. The consistency of the antibacterial activity of the lemongrass ethanol extract needs to be tested for application on the edible film against both those bacteria. The results revealed that lemongrass ethanol extract applied to the alginate based edible film exhibited the ability to inhibit the growth of pathogenic bacteria, particularly $S$ aureus, which was characterized by the formation of a clear zone around the edible film. However, that antibacterial activity was not shown against $E$. coli. The inhibition diameter of lemongrass ethanol extract against pathogenic bacteria of $S$. aureus can be seen in Table 2 and Fig. 8. Thus, it can be emphasized that the alginate based edible film with the addition of lemongrass ethanol extract is effective in inhibiting the growth of $S$. aureus. Based on the clear zone diameters as the effect of antibacterial activity (Table $\mathrm{x}$ ), it can also be concluded that the addition of lemongrass ethanol extract at $0.5 \%$ is considered suitable to produce alginate based antibacterial edible films. The inhibitory effects of lemongrass extract are suspected due to flavonoids, saponins, polyphenols, alkaloids and essential oils [46]. Other chemical components found in the alcohol extracts of lemongrass leaves and stems are tannins, quinones and terpenoids [47]. Flavonoids function as antibacterial by forming complex compounds against extracellular proteins that interfere with the integrity of bacterial cell membranes [48]. Thus, flavonoids work against bacteria by damaging the cytoplasmic membrane. The bacterial cytoplasmic membrane itself functions to regulate the entry of nutrients. When the cytoplasmic membrane is damaged, metabolite compounds in the bacteria come out. For the reason that nutrients required for the production of energy cannot enter and eventually the inability of bacterial cells to grow can cause cell death [49]. Tannins can make bacterial cell walls to shrink, so that cell permeability is disrupted which results in disruption of cell activity and even cell death [50]. Saponins can bring about microbial cell lysis by disrupting the stability of their cell membranes inducing cells to swell and burst [51]. Phenolic, flavonoid, alkaloid and saponin compounds are secondary metabolite compounds that can act as antibacterials with activities such as tetracycline and penicillin antibiotics. [52]. The lemongrass essential oil contains geranial, neral, and mirsen which have antimicrobial activity against Gram-positive and Gram-negative bacteria [53].

Published By: 
Table 2. Antibacterial activity of edible film added with the lemongrass ethanol extract against Staphylococcus aureus and Escherichia coli

\begin{tabular}{|c|c|c|}
\hline $\begin{array}{c}\text { Concentration of } \\
\text { Lemongrass Ethanol } \\
\text { Extract }\end{array}$ & \multicolumn{2}{|c|}{ Inhibition Zone (mm) } \\
\cline { 2 - 3 } & Staphylococcus aureus & $\begin{array}{c}\text { Escherichia } \\
\text { coli }\end{array}$ \\
\hline $0.50 \%$ & 9,10 & 0,00 \\
\hline $1.00 \%$ & 10,20 & 0,00 \\
\hline $1.50 \%$ & 9,60 & 0,00 \\
\hline
\end{tabular}

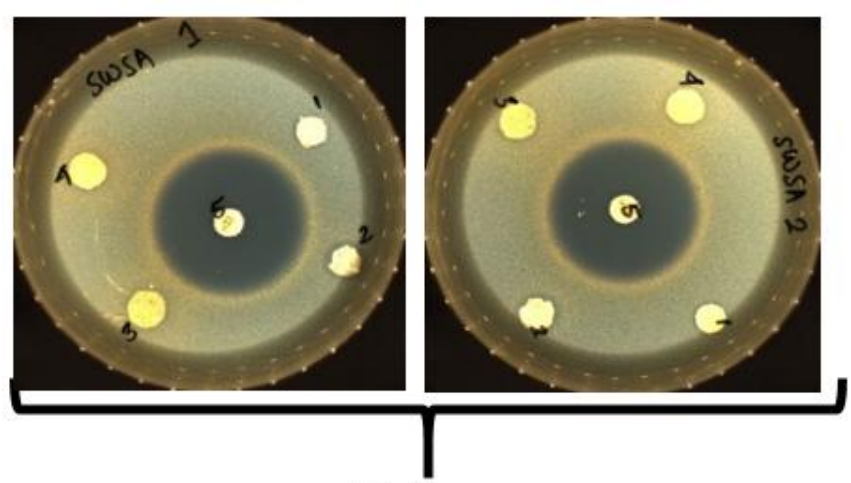

(a) S. aureus

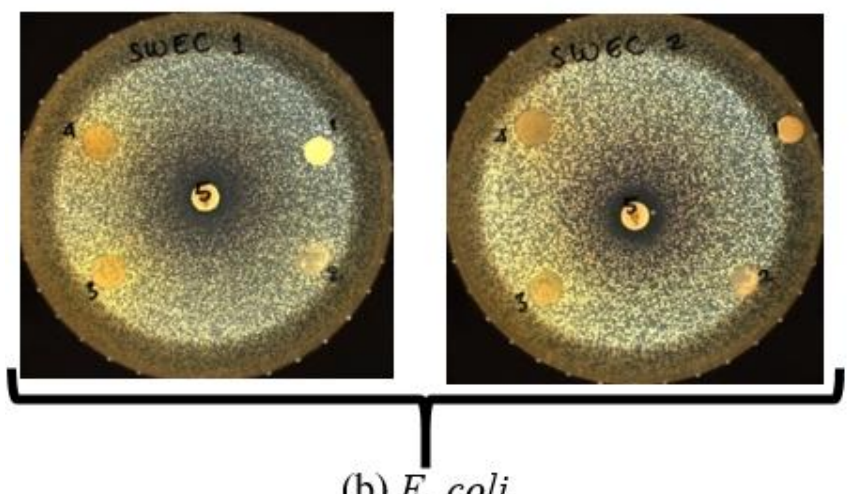

(b) E. coli

Fig. 8 Inhibition zone of edible film added with the lemongrass ethanol extract against Staphylococcus aureus and Escherichia coli

\section{CONCLUSION}

The addition of lemongrass ethanol extract at higher concentration levels improved water vapor transmission rate (WVTR) and elongation percentage of alginate based edible films. Meanwhile, the addition of lemongrass ethanol extract increased water solubility and reduced brightness performance of edible films.

Lemongrass ethanol extract demonstrated antibacterial activity against Staphylococcus aureus and alginate based edible films added with that lemongrass extract also demonstrated antibacterial effect on that bacteria. The addition of $0.5 \%$ lemongrass ethanol extract is considered sufficient for the manufacture of alginate based antibacterial edible film.

\section{ACKNOWLEDMENT}

Sincerely gratitude is addressed by authors to the Ministry of Research, Technology and Higher Education of the Republic of Indonesia, who has provided funding for executing this study through PTUPT program 2020 No: 41.04/USJ-11/H.54/2020. The authors declare that there is no conflict of interest regarding the publication of this article.
Main Contributors: Giyatmi Giyatmi and Hari Eko Irianto. Contributors: Dina Fransiska, Nurhayati and Bintang Anggoro

\section{REFERENCES}

1. A. Rasyid, "Algae Coklat (Phaeophyta) Sebagai Sumber Alginat," Oseana, vol. XXVIII, no. 1, 2003, pp. 33 - 38.

2. W. Mushollaeni and E. Rusdiana, "Karakterisasi Natrium Alginat dari Sargassum sp., Turbinaria sp. dan Padina sp.," J. Teknol. Dan Industri Pangan, vol. XXII, no. 1, 2011, pp. 26-32.

3. I. A. Brownlee, C. J. Seal, M. Wilcox, W. Peter, P. W. Dettmar and J. P. Pearson, "Applications of Alginates in Food," in Alginates: Biology and Applications, B.H A..Rehm, Ed. Berlin, Heidelberg: Springer, 2009, pp. 211-228.

4. N.L.G.S. Dewi, B. Admadi, and A. Hartiati, "Karakteristik Bioplastik Alginat Dari Rumput Laut Ulva lactuca (Tinjauan Suhu Dan Lama Gelatinisasi)," Jurnal Rekayasa Dan Manajemen Agroindustri, vol. 5 , no. 3, 2017, pp. 66 -73.

5. M.D. De’Nobili., L.M. Curto, J.M. Delfino, C.D. Pérez, D. Bernhardt, L.N. Gerschenson, E.N. Fissore and A.M. Rojas, "Alginate utility in edible and non-edible film development and the influence of its macromolecular structure in the antioxidant activity of a pharmaceutical/food interface," In Alginic Acid: Chemical Structure, Uses and Health Benefits, A. Moore, Ed. Hauppauge, NY: Nova Science Publishers, Inc., 2014, pp. 119-169.

6. H.E. Salama, M.S.S.D. Aziz. and M.W. Sabaa, "Novel biodegradable and antibacterial edible films based on alginate and chitosan biguanidine hydrochloride," International Journal of Biological Macromolecules, 116, 2018, pp.443-450.

7. A. Cagri, Z. Ustunol and E.T. Ryser, "Antimicrobial Edible Films and Coatings," Journal of Food Protection, vol. 67, no. 4 2004, pp. 833-848.

8. Miskiyah, Juniawati and E.S. Iriani, "Potensi Edible Film Antimikroba Sebagai Pengawet Daging,” Buletin Peternakan, vol. 39, no. 2, 2015 pp. 129-141.

9. A.F. Mulyadi, M.H. Pulungan and N. Qayyum, "Pembuatan edible film maizena dan uji aktifitas antibakteri (Kajian konsentrasi Gliserol dan ekstrak daun beluntas (Pluchea indica L)," Industria: Jurnal Teknologi dan Manajemen Agroindustri, vol.5, no. 3, 2016, pp. 149-158.

10. M. Maizura, A. Fazilah, M.H. Norziah and A.A. Karim, "Antibacterial activity and mechanical properties of partially hydrolyzed sago starch-alginate edible film containing lemongrass oil," J. Food Sci., vol. 72, no. 6, 2007, pp..c324-c330.

11. Y. Pranoto, V.M. Salokhe and S.K. Rakshit, "Physical and antibacterial properties of alginate-based edible film incorporated with garlic oil," J. Food Res. Intl. 38: 2005, pp.267-272.

12. Miksusanti, Herlina, and K.I. Masril, "Antibacterial and Antioxidan of Uwi (Dioscorea Alata L) Starch Edible Film Incorporated with Ginger Essential Oil. International Journal of Bioscience, Biochemistry and Bioinformatics, vol. 3, no.4, 2013, pp.354-356.

13. J. Kusnadi and P. Budyanto, "Antibacterial Active Packaging Edible Film Formulation with Addition Teak (Tectona grandis) Leaf Extract," International Journal of Life Sciences Biotechnology and Pharma Research, vol. 4, no. 2, 2015, pp. $79-84$.

14. Sarlina, A.R. Razak and M.R. Tandah, "Uji Aktivitas Antibakteri Sediaan Gel Ekstrak Daun Sereh (Cymbopogon nardus L. Rendle) terhadap Bakteri Staphylococcus aureus Penyebab Jerawat," Jurnal Farmasi, vol. 3, no. 2, 2017, pp 143 - 149.

15. U. Mayasari and A. Sapitri, "Uji Aktivitas Antibakteri Daun Sereh Wangi (Cymbopogon nardus) Terhadap Pertumbuhan Bakter Streptococcus mutans, " Klorofil, vol. 3, no. 2, 2019, pp.15-19.

16. Soraya, C., Sunnati and Maulina, V. 2016. Efek Antibakteri Ekstrak Batang Serai (Cymbopogoncitratus) Terhadap Pertumbuhan Enterococcus faecalis. Cakradonya Dent J .8(2):69-78.

17. M. I. Naik, B. A. Fomda, E. Jaykumar and J. A. Bhat, "Antibacterial activity of lemongrass (Cymbopogon citratus) oil against some selected pathogenic bacterias", Asian Pacific Journal of Tropical Medicine, 2010, pp. 535-538.

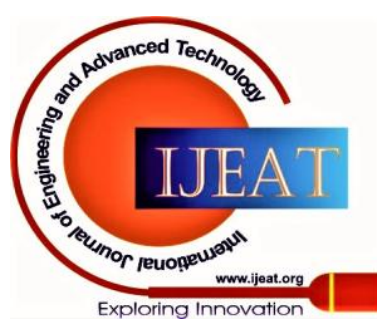


18. Yunizal, "Teknologi Ekstraksi Natrium Alginatdari Rumput Laut Coklat (Phaeophyceae)," In. Teknologi Pemanfaatan Rumput Laut, Eds. N. Aji. F. Ariyani and T.D. Suryaningrum, Jakarta: Pusat Riset Pengolahan Produk dan Sosial Ekonomi Kelautan dan Perikanan, 2003, pp.14-17.

19. P. Sitorus, "Uji Efek Kombinasi Amoksisilin dengan Ekstrak Etanol Daun Sirih (Piper betle L) terhadap Pertumbuhan Bakteri Escherichia coli dan Staphylococcus aureus," In: TM Conference Series, 2018, pp. 01: 313-319.

20. Murdinah, M. Darmawan and D. Fransiska, "Karakteristik Edible Film dari Komposit Alginat, Gluten, dan Lilin Lebah (Beeswax)," J Pascapanen dan Bioteknol Kelaut dan Perikan, vol. 2, no. 1, 2007, pp.19-25..

21. I. Syaichurrozi, N. Handayani and D.H. Wardhani, "Karakteristik Edible Film Dari Pati Ganyong (Canna edulis Kerr.) Berantimikroba. Jurnal Teknologi Kimia dan Industri, vol. 1, no. 1, 2012, pp. 305-311

22. American Society for Testing and Materials (ASTM), "ASTM E96/E96M-10 Standard Testing Methods for Water Vapor Transmission. Annual Book of ASTM Standatrd," https://doi.org/10.1520/E0096_E0096M-10.

23. H.E. Irianto, Agusman, D. Fransiska and Musfira. "Mechanical and Barrier Properties of Composite Films Based on Kappa-Carrageenan-Polyvinyl Alcohol,” IJEAT, Vol. 8, Issue-6S3, September 2019, pp. 489-499.

24. A. I. Balqis, M. N. Khaizura, A. R. Russly and Z. N. Hanani, Effects of plasticizers on the physicochemical properties of kappa-carrageenan films extracted from Eucheuma cottonii," International Journal of Biological Macromolecules, 103, 2017, pp. 721-732..

25. Badan Standardisasi Nasional, "SNI 2354.2:2015 Cara Uji Kimia Bagian 2: Pengujian Kadar Air pada Produk Perikanan," Jakarta: Badan Standarisasi Nasional, 2015, p. 8.

26. S, W. Murni, H. Pawigno, Widyawati and N. Sari, "Pembuatan edible film dari Tepung Jagung (Zea mays L.) dan Kitosan," In Proceeding of Seminar Nasional Teknik Kimia : Kejuangan. Yogyakarta, 5 Marc 2013. Yogyakarta: Universitas Pembangunan Nasional "Veteran, 2013, pp. 1-9.

27. M. da Silva, B. Lamanaka, M. Taniwaki and T. Kieckbusch, "Evaluation of the Antimicrobial Potential of Alginate and Alginate/ Chitosan Films Containing Potassium Sorbate and Natamycin," Packaging Technology and Science, vol. 26, no.8, 2013, pp. 479-492

28. R. Muin, D. Anggraini, and F. Malau, "Karakteristik Fisik Dan Antimikroba Edible Film Dari Tepung Tapioka Dengan Penambahan Gliserol Dan Kunyit Putih,” Jurnal Teknik Kimia, vol. 3, no. 23, 2017, pp. 191-198.

29. Giyatmi, S. Melanie, D. Fransiska, M. Darmawan and H.E. Irianto, "Barrier and Physical Propwerties of Arrowroot Starch - Carrageenan Based Biofilms," J Bio-Sci., vol. 25, 2017, pp. 45-56.

30. B. Santoso, Z. Hilda, G. Priyanto and R. Pambayun, "Perbaikan Sifat Laju Transmisi Uap Air dan Antibakteri Edible Film Dengan Menggunakan Minyak Sawit dan Jeruk Kunci. Agritech, vol. 37, no. 3, 2017, pp. 263-270.

31. G.O. Lim, S.A. Jang and K.B. Song, "Physical and antimicrobial properties of Gelidium corneum/nanoclay composite film containing grapefruit seed extract or thymol," Journal of Food Engineering, vol. 98 (2010, pp. 415-420.

32. E. Warsiki, T.C. Sunarti and R.D. Martua, "Pengembangan Kemasan Antimicrobial (AM) Untuk Memperpanjang Umur Simpan Produk Pangan," In Prosiding Seminar Hasil-Hasil Penelitian. Bogor: Institut Pertanian Bogor, 2009, pp. 579-588.

33. I. Zuwanna, Fitriani and H. Meilina, "Pengemas Makanan Ramah Lingkungan, Berbasis Limbah Cair Tahu (Whey) Sebagai Edible Film," In Prosiding Seminar Nasional Pascasarjana (SNP) Unsyiah 2017. Banda Aceh, April 13, 2017. Banda Aceh: Universitas Syiahkuala, pp. A277 - A287.

34. K. Qotimah, E.N. Dewi and L. Purnamayati. "Karakteristik Muitu Edible Film Karagenan Dengan Penambahan Minyak Atsiri Bawang Putih (Allium sativum) Pada Produk Pasta Ikan,” JPHPI, vol. 23, no.1, 2020, pp. 1-9.

35. I.D.A. Wirawan, A.R. Pratiwi and V.K. Ananingsih, "Aplikasi Karagenan Eucheuma cottonii dengan Penambahan Minyak Sawit dalam Pembuatan Edible Film. Jurnal Aplikasi Teknologi Pangan, vol. 6, no. 4, 2017, pp.145-149.

36. M. Tanaka, S. Ishizaki, T. Suzuki and R. Takai, "Water vapor permeability of edible films prepared from fish water soluble proteins as affected by lipid type," Journal of Tokyo University of Fisheries, vol. 87. 2001, 31-37.

37. H.E.Irianto, M. Darmawan and M. Endang, "Pembuatan edible film dari komposit karaginan, tepung tapioka dan lilin lebah (beeswax),"
Jurnal Pascapanen dan Bioteknologi Kelautan dan Perikanan, vol. 1 no. 2, 2006, pp. 93-101.

38. R. Thakur, P. Pristijono, J. B. Golding, C. E. Stathopoulos, C. J. Scarlett, M. Bowyer, Q. V. Vuong, "Amylose-lipid complex as a measure of variations in physical, mechanical and barrier attributes of rice starch- 1 -carrageenan biodegradable edible film," Food Packaging and Shelf Life, vol. 14, 2017, pp. 108-115.

39. Warkoyo, B. Rahardjo, D.W. Marseno and J.N.SW. Karyadi, "Sifat Fisik, Mekanik Dan Barrier Edible Film Berbasis Pati Umbi Kimpul (Xanthosoma sagittifolium) Yang Diinkorporasi Dengan Kalium Sorbat," Agritech, vol. 34, no. 1, 2014, pp. 72-81.

40. R.E. Ariska and Suyatno, "Pengaruh konsentrasi karagenan terhadap sifat fisik dan mekanik edible film dari pati bonggol pisang dan karagenan dengan plasticizer gliserol," In Prosiding. Seminar Nasional Kimia. Surabaya, 3-4 Oktober 2015. Surabaya: Jurusan Kimia FMIPA - Universitas Negeri Surabaya, 2015, pp. C34 - C 40.

41. A. Manab, "Pengaruh penambahan minyak kelapa sawit terhadap karakteristik edible film protein whey," Jurnal Ilmu dan Teknologi Hasil Ternak, vol. 3, no. 2, 2008. 8-16.

42. I. D. A. Wirawan, A. R.Pratiwi and V. K. Ananingsih, "Aplikasi Karagenan Eucheuma cottonii dengan Penambahan Minyak Sawit dalam Pembuatan Edible Film," Jurnal Aplikasi Teknologi Pangan, vol. 6, no. 4, 2017, pp. 145-149

43. Giyatmi, T.A.E Poetri, H.E. Irianto, D. Fransiska and Agusman, "Effect of Alginate and Polyethylene Glycol Addition on Physical and Mechanical Characteristics of k-Carrageenan-based Edible Film," Squalen Bull Mar Fish Postharvest Biotech, vol. 15, no. 1, 2020, pp. $41-51$.

44. R. Handayani and H. Nurzanah, "Karakteristik edible film pati talas dengan penambahan antimikroba dari minyak atsiri lengkuas. Jurnal Kompetensi Teknik, vol. 10, no. 1, 2018, pp. 1-11.

45. A. Rusli, Metusalach, Salengke and M.M. Tahir, Karakterisasi Edible Film Karagenan Dengan Pemlastis Gliserol. JPHPI, vol 20, no. 2, 2017, pp. 219-229.

46. S.S. Syamsuhidayat and J.R. Hutapea, Inventaris Tanaman Obat Indonesia. Jakarta: Departemen Kesehatan Republik Indonesia, 1991, p. 616.

47. A.P. Verawati, K. Anam and D. Kusrini, "Identifikasi Kandungan Kimia Ekstrak Etanol Serai Bumbu (Andropogon citratus D.C.) dan Uji Efektivitas Repelen Terhadap Nyamuk Aedes aegypti," Jurnal Sains dan Matematika, vol. 21, no. 1, 2013, pp. 20-24.

48. F. Juliantina, D.A. Citra, B. Nirwani, T. Nurmasitoh and E.T. Wibowo, "Manfaat Sirih Merah (Piper crocatum) sebagai Agen Anti Bakterial Terhadap Bakteri Gram Positif Dan Bakteri Gram Negatif," Jurnal kedokteran dan kesehatan Indonesia, vol. 1, no. 1, 2009, pp.12-20.

49. U. Mayasari and A. Sapitri. "Uji Aktivitas Antibakteri Daun Sereh Wangi (Cymbopogon nardus) Terhadap Pertumbuhan Bakteri Streptococcus mutans, " Klorofil, vol. 3, no. 2, 2019, pp.15-19.

50. F. Kawengian, S. Wuisan and A. Leman, "Uji Daya Hambat Ekstrak Daun Serei (Cymbopogon citatrus L) Terhadap Pertumbuhan Streptococcus mutans," Jurnal e-GiGi (eG), vol 5, no. 1, 2017, pp. 7-11.

51. E. Fitriani, M. Alwi, and D. Umrah, "Studi Efektivitas Ekstrak Daun Sereh Wangi (Cymbopogon nardus L.) sebagai Anti Fungi Candida albicans," Jurnal Biocelebes, vol..7, no. 2, December 2013, pp. 15-20

52. S.M. Astuti, "Skrining Fitokimia dan Uji Aktifitas Antibiotika ekstrak etanol daun, batang, bunga dan umbi tanaman Binahong (Enredera cordifolia (Ten) Steenis)," Buletin Pengujian Mutu Obat Hewan, vol. 19, 2013, pp. 61-68.

53. M.S. Howarto, P.M. Wowor and C.N. Mintjelungan, Uji efektivitas antibakteri minyak atsiri sereh dapur Sebagai Bahan Medikamen Saluran Akar Terhadap Bakteri Enterococcus faecalis. Jurnal e-GiGi (eG), vol. 3, no. 2, 2015, pp.432-438.

Published By:

Blue Eyes Intelligence Engineering and Sciences Publication (C) Copyriaht: All rights reserved. 


\section{AUTHORS PROFILE}

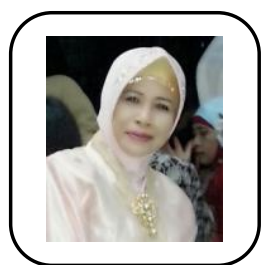

Giyatmi Giyatmi, is currently a Professor in Food Technology at the Study Program of Food Technology, Sahid University, Jakarta, Indonesia. She was graduated for his PhD in Food Science from Bogor Agricultural University / IPB University, Bogor, Indonesia. She has served as a lecturer at the Study Program of Food Technnology, Sahid University since 1994. She has actively involved in several professional organizations, i.e. as Division Head of Research and Community Service - The Indonesian Lecturers Association, Jakarta Province, Division Head of Organization - The Indonesian Food Technologist Association, Division Head of Research The Indonesian Private Universities Association, Jakarta Province as well as Central Board of Lemhannas Alumni Association (2015-present). She has written several books and many articles related to the foods.

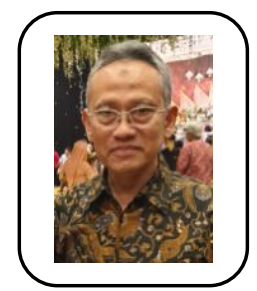

Hari Eko Irianto is currently a Research Professor in fisheries post-harvest technology at the Research and Development Center for Marine and Fisheries Product Processing and Biotechnology and a Professor in food technology at the Faculty of Food Technology and Health, Sahid University, Jakarta, Indonesia. He was graduated for his $\mathrm{PhD}$ in Food Technology (Food Process and Product Development), from Massey University, New Zealand in 1992. He is journal editors for some Indonesian journals, i.e. Jurnal Pascapanen dan Bioteknologi Kelautan dan Perikanan (Indonesian), Jurnal Pengolahan Hasil Perikanan Indonesia (Indonesian), and Squalen - Bulletin of Marine and Fisheries Postharvest and Biotechnology (English). He is also invited reviewers for several domestic and International journals. He has published more than 180 scientific papers in national accredited journals, International journals, book chapters, and proceedings. He has also published some books. His research interest is Fish processing technology including food safety. He is a member of the Indonesian Academy of Food and Nutrition Sciences. He is also advisor members of the Indonesian Fisheries Product Processing Society and the Indonesian Biotechnology Consortium. During the period of 2005 - 2020, he has served as directors of several research centers, i.e. Indonesian Research and Development Center for Marine and Fisheries Product Processing and Biotechnology, Indonesian Research Center for Fisheries Management and Conservation, Indonesian Research and Development of Marine and Fisheries Technology, as well as Indonesian Research and Development Center for Fisheries.

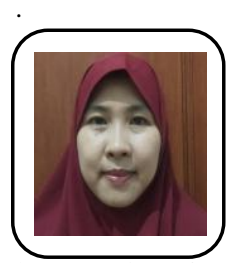

Dina Fransiska is currently a researcher at the Research and Development Center for Marine and Fisheries Product Processing and Biotechnology, Jakarta, Indonesia.. She joined the center started 2005. She obtained Master degree from Diponegoro University, Semarang, Indonesia. Her reasearch interest is seaweed product development, including the extraction of agar bacto, alginate and agar, edible film, and bioplastics from seaweed... Several scientific publications and books have been produced.

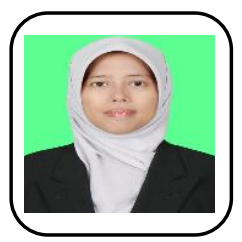

Nurhayati is a researcher with a focus on marine and fishery products processing including the extraction of alginate and agar, edible film, and bioplastics from seaweed, biofertilizers, fish feed, cellulose acetate, and art paper from seaweed processing by-products, as well as calcium and collagen from fisheries processing by-products starting 2012. Several publications have been produced in the form of books as well as research and scientific review articles published in journals.

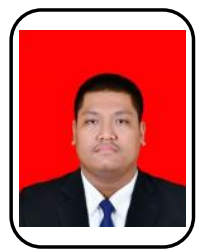

Bintang Anggoro is a graduate of the Department bof Food Technology, Sahid Unibversity, Jakarta, Indonesia. She has involved in 2017 Food Day event and food bussiness incubator. He has participated in a research on the development of alginate based antibacterial edible film using several plant extract as an antibacterial.

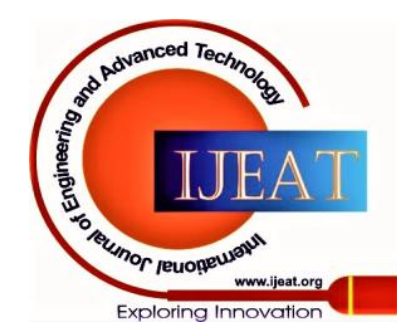

